\title{
USING TRADITIONAL APPROACHES TO THE UPBRINGING OF CHILDREN WITH HEARING IMPAIRMENTS AND REHABILITATION OF CHILDREN USING ALL THE RESOURCES OF THE BODY
}

\section{Feruza Shuhratovna Mustafakulova}

Master Student, Tashkent State Pedagogical University, Tashkent, Uzbekistan

Dilnoza Dilmurod Qizi Latifxadjayeva

Master Student, Tashkent State Pedagogical University, Tashkent, Uzbekistan

\section{ABSTRACT}

In this article, along with the use of traditional approaches to the upbringing of children with hearing and speech impairments, the desire of specialists working with this category of children to expand knowledge in the field of rehabilitation and education of children with hearing and speech impairments, using the experience of world special pedagogy, turning to modern technologies, is analyzed.

KEYWORDS: - A child with hearing impairment, verbatonic method, audiovisual method, oral speech, ontogenesis.

\section{INTRODUCTION}

Language learning is based not only on a new technology of pedagogical work with deaf children, but also on the so-called verbotonic method, which involves the use of original hearing aids of a new generation, taking into account significant hearing loss by the deaf not only in terms of voice strength, but also in the frequency range.

\section{Materials AND METHOdS}

The verbonic method is a method of rehabilitation of children, using all the resources of the body for the development of oral speech and integration into society.

\section{Tasks of the verbotonic method:}

Creating the child's need and motivation to listen and speak.

Formation of a database of development indicators (4 indicators - breathing, voice, rhythmic intonation of speech, voice formation).

Development of auditory perception.

The verbotonic method as a system is based on the nature of speech development in 
CURRENT RESEARCH JOURNAL OF PEDAGOGICS 2(12): 106-109,

December 2021 DOI: https://doi.org/10.37547/pedagogics-crjp-02-12-21

ISSN 2767-3278

(C)2021 Master Journals

Crossref dof 81 Google

Accepted $18^{\text {th }}$ December, 2021 \& Published 23 th December, 2021

ontogenesis, according to which the child's vocal activity reacts to vocal and proprioceptive sensations (sensations of the whole organism).The verbose system is the rehabilitation of a person, first of all, the rehabilitation of residual auditory perception, the activation of all preserved analyzers, the potential capabilities of a person. On the basis of residual auditory perception, the child's speech develops-it is the main one in the system of verbal education.

Elements of the Verboton system:

- The phase of vibration exposure

- Audiovisual courses

- Phonetic rhythm

- Musical stimulation

- Pictographic rhythm

The audiovisual method (AVM) is a method of learning a language in a short time on limited lexical and grammatical material characteristic of the conversational style of speech, using visual means. The full name of the method that conveys its properties well is "audiovisual structurally global", that is, the new material is intended primarily for listening, and its meaning is for visual perception. Language learning is carried out by assimilation of globally (holistically) accepted structures (sentence models, speech patterns).

This method of teaching appeared in France in the 50s.due to the great interest in the problem of mastering foreign spoken language, it began to manifest itself in a short time.

The theoretical foundations of the method were developed at the research center for the study and dissemination of the French language abroad (credif Center for recherche and d'Etude for challenge of Francais), part of the Pedagogical Institute of Saint-Cloud and created by J. Led by the Huguenots. Under his leadership and P.
Rivanka, K. Ma-Landen, D. Mialare, Yugoslavia Professor P. Having selected and characterized the educational material for working according to the methodology with the active participation of Guberina, in 1962 the first audiovisual course of the French language "sounds and images of France" was published.

Today, AVM remains one of the most popular methods of teaching foreign languages. (According to UNESCO, about 50\% of foreign language learners use this method abroad.) In its pure form, the method is used mainly in shortterm foreign language courses for adults.

The audiovisual global-structural method is an integral part of the geobotanical method. The authors of this method are Academician P. Gubina (Zagreb, Croatia) and Professor P. Rivens (Paris, France).

The main purpose of oral speech is communication. The audiovisual course contains all the theoretical provisions of speech linguistics, language understanding and communication and is an integral part of the verbotonic method.

The auditory sense plays an important role in the formation and development of speech. The auditory and sound images correspond to the meaning-the picture. The picture is connected with the situation-reality. The painting depicts not only things, people, but also specific situations from everyday life.

Audiovisual, in other words-sound and picture. The main language form of the alphabet is the image accompanying the sound (speech). Language and speech are perceived by hearing, vision, and movement. The role-playing picture is post-apocalyptic. At the beginning it is unacceptable, and at the end of the course it is removed when the expression of the language is adequate and accompanied by a full turn of the action. 
CURRENT RESEARCH JOURNAL OF PEDAGOGICS 2(12): 106-109,

December 2021 DOI: https://doi.org/10.37547/pedagogics-crjp-02-12-21

ISSN 2767-3278

(C)2021 Master Journals

Crossref dof 81 Google

Accepted 18 ${ }^{\text {th }}$ December, 2021 \& Published 23 ${ }^{\text {th }}$ December, 2021

Picture value:

1. connects the expression with the real situation,

2. helps with voice memory,

3. it allows you to understand simple signs in the language.

Researches

Performed the AVM methodology with schoolchildren.

Demonstration and memorization stage

Students are well versed in the situation, memorize the text. The picture appears 2-3 seconds before the sound. 2 times in a row it was recommended to watch and listen to AVM. After that, the students began to repeat the pictures of the phrase. When repeating, I worked on pronunciation. It was the longest stage.

Explanation stage

I explained the content of the text and worked on understanding it.

The stage of dramatization

This stage may include various works: students repeated the text according to their roles until each of them played at least one role.

\section{Activation phase}

I asked questions about the pictures;

readers asked each other questions about the pictures;

I asked questions without relying on photos;

readers asked each other questions without relying on pictures;

the students drew separate pictures;

readers translated the text into pictures;

readers translated the text without relying on pictures;
Then I asked the students questions about similar situations in the life of students;

readers have suffered similar situations from their lives.

The ultimate goal of AVM is to translate speech material into independent speech, expand and enrich the speech practice of younger schoolchildren with hearing impairments. At the same time, the speech activity of students in the classroom increases, the proportion of independent words increases, initiative speech develops. The use of AVM in extracurricular activities provides a speech environment for students throughout the day, encouraging the deaf to use spoken language to communicate with others.

Ultimately, the goal of all work on the development of speech of hard-of-hearing younger schoolchildren should be the desire to lead a deaf child to master oral speech so that it is understandable to others and so that the child's speech addressed to him is understandable not only to his teachers, but also to those who speak in general.

In the practice of teaching deaf students, there is experience in using AVC (Zagreb, Croatia, Zelenograd, Khabarovsk, Kiev, etc.), which gives good results.The development of the speech of deaf-mute high school students is an important part of a special (correctional) school for deaf children, so we also decided to put AVK into practice. We used this course mainly in speech development classes. At the same time, the work was carried out in individual classes on RSV and pronunciation formation, in music and rhythmic classes, in auditory work aimed at pronunciation and intonation. In all these classes, the children perceived the same topic, the same vocabulary was developed, the same pictures were considered.

At the first presentation of the drawing, they 
CURRENT RESEARCH JOURNAL OF PEDAGOGICS 2(12): 106-109,

December 2021 DOI: https://doi.org/10.37547/pedagogics-crjp-02-12-21

ISSN 2767-3278

(C)2021 Master Journals

Crossref do) 81 Google

Accepted 18 ${ }^{\text {th }}$ December, 2021 \& Published 23 $3^{\text {th }}$ December, 2021

were arranged in strict order, examined under the guidance of a teacher, and each image was accompanied by a plate. To hear or hear a text is a visual perception. Then work was carried out on the content of the text or conversation. Let the children understand the text, establish a sequence of pictures arranged in any order, tell one picture at a time, name the missing pictures, create similar situations from their own experience, etc. k. After the children have mastered the necessary vocabulary on the topic, proceed to conversations.

For each topic, the initial and final Control work is carried out (description of the drawing, communication on a specific topic). Based on the results of the experiment, we concluded that the vocabulary of students has significantly expanded, speech has become more emotional, children are bolder in making contact with hearing. Therefore, the use of an audiovisual course of the verbotonic method is an effective condition for the development of speech of younger schoolchildren with hearing impairments. And overcoming the consequences of deafness, the possibility of integration into a group of listeners, into public life largely depends on the level of speech development.

\section{Conclusion}

From the analysis conducted, it is possible to draw the following conclusions:

1. The need and desire of the student to communicate by oral speech have been formed;

2. The student's self-control over his own voice and speech has been formed;

3. Contributed to the development of tactile, emotional, intonated speech;

4. It was found that the child pays more attention to his speech and less attention to his facial expressions and gestures;
5. It is established that learning the correct repetition of any speech phrase allows you to independently combine popular words into sentences.

Since the state of speech is built in the form of communication, which is the main language form, the audiovisual global-systemic method allows for faster and easier development of independent speech in children with hearing impairment.

\section{REFERENCES}

1. Rau F.F. Formation of oral speech in deaf children. - M.: type.: Pedagogy, 1981. - 280 p.

2. Mamarajabova Z.N. Special methods of teaching the native language-Tashkent2015. - 26 p.

3. Bozavli, E. (2017). Vocabulary Teaching in Foreign Language via Audiovisual Method Technique of Listening and Following Writing Scripts. International Education Studies, 10(5), 129-135.

4. Van Eijk, R. L., Kohlrausch, A., Juola, J. F., \& van de Par, S. (2008). Audiovisual synchrony and temporal order judgments: effects of experimental method and stimulus type. Perception \& psychophysics, 70(6), 955-968.

5. Khandelwal, D., Kalra, N., Tyagi, R., Khatri, A., \& Gupta, K. (2018). Control of anxiety in pediatric patients using "Tell Show Do" method and audiovisual distraction. J Contemp Dent Pract, 19(9), 1058-1064. 